\title{
Article
}

\section{International Trade in the High-Tech Sector-Support or Obstacle to Start-Up Processes at the Macro Level in European Union Countries?}

\author{
Aleksandra Gawel (D) \\ Department of International Competitiveness, Poznan University of Economics and Business, Al. Niepodległosci \\ 10,61-875 Poznan, Poland; aleksandra.gawel@ue.poznan.pl
}

Citation: Gawel, A. International

Trade in the High-Tech

Sector-Support or Obstacle to

Start-Up Processes at the Macro Level in European Union Countries? J.

Theor. Appl. Electron. Commer. Res. 2021, 16, 1877-1892. https://doi.org/ $10.3390 /$ jtaer16050105

Academic Editor: Krzysztof Wach

Received: 11 May 2021

Accepted: 8 June 2021

Published: 10 June 2021

Publisher's Note: MDPI stays neutral with regard to jurisdictional claims in published maps and institutional affiliations.

\begin{abstract}
High-tech internationalization touches on two aspects impacting entrepreneurship: openness of the economy and its level of innovativeness. Both of them might positively or negatively affect the process of new company creations, as suggested by the concept of entrepreneurial regime with creative destruction or by the concept of routinized regime with creative accumulation. The aim of the article is to assess the impact of high-tech internationalization on the start-up process of new company creation. Cluster analysis and panel modeling for European Union countries in 2009-2018 were conducted. The research results distinguish clusters of European Union countries with a different level of high-tech internationalization. The impact of high-tech internationalization on start-up rates is significant in the case of both clusters; however, it is stronger in the cluster of countries with a relatively higher level of high-tech international openness. The high-tech intra-EU import and extra-EU high-tech export negatively affect the rate of new enterprise creation in both clusters. Additionally, extra-EU import in clusters with a relatively higher level of high-tech internationalization also negatively impacts start-up rates. The only aspect supporting the start-up process is the level of intra-EU export in clusters with higher levels of high-tech internationalization. The results suggest that in European Union countries, creative accumulation is the dominant phenomenon.
\end{abstract}

Keywords: high-tech international trade; start-up process; European Union

\section{Introduction}

Companies in the high-tech sector, although operating globally in the process of internationalization, are also still active locally and nationally, as they run their daily operations in some space, interacting with local actors in entrepreneurial ecosystems. The internationalization of the high-tech sector includes two aspects influencing entrepreneurship: the openness of the economy and the level of its innovation and technological advancement. Both of these aspects can positively and negatively affect the process of creating new enterprises. Internationalization of the high-tech sector can support the start-up process through greater openness to the creation and implementation of new technological solutions to the market by newly-created companies, which is observed in entrepreneurial regimes and in the process of creative destruction. However, as is observed in routinized regimes and the process of creative accumulation, the development and international openness of the high-tech sector may be a factor limiting the development of new enterprises when this sector creates competitive conditions in favor of established enterprises and, thus, constitutes a barrier to market entry for new firms.

The main aim of the article is to answer the research question of whether the internationalization of the high-tech sector contributes to the start-up process of new company creation from the perspective of the country macro-level. Most research on high-tech internationalization focuses on internal and external factors that affect high-tech companies in becoming international [1,2], choosing their strategy of internationalization [3] or choosing the entry mode [4]. However, the novelty of this paper is the assumption that the inter- 
nationalization of the high-tech industry, within the entrepreneurial ecosystem, creates a competitive environment in the country of origin for all established and start-up companies, an environment that is highly innovative, risk-taking, investment intensive, knowledge intensive, and open to the diffusion of innovation and global trends. Due to these, by shaping the competitive environment of the country of origin, the internationalization of the high-tech industry is supposed to affect entrepreneurship.

However, as countries differ regarding the level of internationalization of the high-tech industry, these observed differences lead to formulating the next two research questions: to what extent is the expected effect of high-tech internationalization on start-up activities moderated by the level of international openness of the high-tech industry, and in which group of countries, with lower or with higher levels of high-tech internationalization, is this assumed influence stronger?

To answer these questions, European Union countries were selected as the research sample, for several reasons. EU countries represent a relatively similar level of institutional backgrounds, especially in the context of the common political framework of international and innovation policies. Additionally, free international trade within the European Union leads to distinguishing the internationalization of high-tech industry in intra-EU and extra-EU contexts. Two research methods were implemented: cluster analysis, to divide EU countries into clusters with similar level of high-tech internationalization; and panel modelling, for estimating interactions between measures. Yearly data for 2009-2018 were carried out.

The research results made it possible to distinguish clusters of European Union countries with a different level of internationalization in the high-tech industry, which indicates internal differentiation among EU members. A stronger impact of the internationalization of the high-tech sector on the rate of creation of new enterprises is observed in the cluster of countries with a relatively higher level of international openness, although this impact is significant in the case of clusters of countries with both higher and lower levels of sector internationalization. However, this impact is negative; the scale of high-tech imports within the EU, and in the case of countries with a higher level of high-tech internationalization, also from outside the EU, have a particularly strong and negative impact on the rate of new firm creation. High-tech exports outside the EU also have a negative impact on the rate of new enterprise creation. The only aspect supporting the start-up process is the level of exports within the EU in the case of countries belonging to the cluster with a relatively high level of high-tech internationalization. Summing up, the results of the research suggest that in the European Union countries, the phenomenon of creative accumulation is dominant.

The paper is structured as follows: First, the theoretical discussion on high-tech industry and its internationalization and its theoretical impact on the start-up process in the countries of origin are presented. Then, the development of research questions and the research method and its results are presented. The final part of the paper is devoted to conclusions and limitations.

\section{Internationalization of High-Tech Sector and Its Effect on Start-Up Process-Theoretical Discussion}

\subsection{High-Tech Sector and Its Internationalization-Theoretical Insights of Its Importance}

The high-tech industry is recognized due to its specific features, which distinguish it from traditional industries. Companies operating in high-tech industries face rapid changes in technology, along with a need for market and customer knowledge, as they operate in a proactive industry with innovative dynamism [5]. They are knowledge- and technology-intensive and highly competitive [6,7]. Technology-based companies are also considered high-risk and high-return [1]. As some high-tech companies conduct their activities in small and global niche markets, they react proactively and quickly to exploit market opportunities [3].

One of the core features of high-tech companies is their innovativeness, as the development of high-tech industry is a process related to technological innovation and industrialization, impacting both economic and technical advantages [8]. Innovation means 
new products, meaning a new solution for a company or improved products; or novel products, meaning a novelty for the whole market $[9,10]$. Research and development (R\&D) activity is often associated with innovations [10-12], as R\&D lead to the development of firm-specific assets that are difficult for competitors to follow and support the achievement of the competitive advantage [13].

Internationalization is one of the key factors for high-tech companies to achieve their competitive advantages [6] as they often operate in small and global niche markets [3]. Internationalization is often perceived as the driving force of economic growth and competition [14]. Internationalization is a broad concept, and from a broad perspective, it can be defined as any activity undertaken abroad [15]; however, in many papers, internationalization is associated with the internationalization of sales, which is not equivalent [16]. Generally, the holistic approach to internationalization relates it to participation in overseas operations, interactions, relationships, and networks [2].

There are several theories explaining the internationalization of companies, among which the Uppsala model is treated as the traditional one and is developed in other models $[2,14,15,17]$. This group of models assumes that internationalization is a stage process, in which companies go from less to more developed forms of activities, starting from activities at local, through regional and national, to international markets. The next set of internationalization models is related to resource theories and assumes that entering the international market depends on the competitive advantage of companies gained through the different kinds of possessed resources [18]. Another attitude is the business network approach to internationalization $[7,16]$, which assumes that companies become international within the business network. Generally speaking, in these groups of theories, internationalization is treated as a feature of well-developed companies already established on the market.

From the point of view of the high-tech industry, the models of rapid or early internationalization seem to be of high importance [15]. Based on the common features of some relatively young companies related to their speed, scale, and scope of internationalization [19], a group of newly-created companies, which are international from the beginning of their existence, was indicated [20]. Such internationalization models and companies are known as born global companies [21]; international new ventures [22,23]; and early, or fast, internationalization [24], and are often associated with high-tech companies [25].

There are several factors impacting the internationalization of companies indicated in the research results, such as, for example, the company's age [26], product, and target group differences [21]; differences in national markets impacting the possibilities of product promotion [27]; or entrepreneurs' ability to recognize and exploit international business opportunities [22]. Features of industry, such as its global integration, international and local competitiveness, affect the time of entry to international markets [28]. From the point of view of the high-tech industry, the technological competences of companies [19], being one of the internationalization determinants, seems to be particularly important. The internationalization of high-tech companies is determined by their technological capabilities [1], innovation performance, and team creativity [2]. The internationalization of the high-tech sector can even be treated as the internationalization of innovations [29].

The internationalization of high-tech companies often starts shortly after company creation and is known as the early or rapid internationalization of born global companies [3,4]. This speed in internationalization is related to the willingness of high-tech companies to cover costly R\&D investments [4]. Technological industries are shaped by technological competences; their degree of technological intensity affects their early internationalization [25]. However, the framework of the Uppsala internationalization model is also used to explain the internationalization of high-tech companies, as the characteristics and competences of decision-makers are still important factors in undertaking international entry among these companies [30]. Although the early and rapid internationalization of high-tech companies is one that most frequently attracts researchers, it is, however, also believed to be one of the least researched [24]. 
The internationalization of high-tech companies, especially start-ups, is also explained by their access to insufficient resources to commercialize their technology on their own. Thanks to internationalization, high-tech start-ups can acquire the necessary resources globally via entry into new networks [16].

\subsection{Internationalization of the High Tech Industry as an Entrepreneurial Ecosystem Shaping the Start-Up Process}

Although high-tech companies are globally active in the process of their internationalization, they still operate in some regional and national contexts related to the location of their headquarters and daily operations. In this context, high-tech companies can be perceived as actors in local entrepreneurial ecosystems, interacting with others.

The paper argues that, as they are actors in the entrepreneurial ecosystem, the hightech industry affects the conditions for the set up and development of new businesses. The start-up process, meaning the process of new company creation, is the narrow understanding of entrepreneurship [31-33], as all entrepreneurial competences are engaged in this process. The establishment of a new company is a process of a long series of complex decisions [34] based on relationships among nascent entrepreneurs, their institutional environment, and market opportunities [35], impacted by factors of different kinds; however, previous research shows conflicting results for start-up process determinants [36]. Start-up companies are heterogeneous as they can be grouped in a relatively large number of companies that imitate existing ideas, a relatively small group of companies that implement minor innovations, and a small share of start-ups introducing radical innovations [33].

Although the aim to explain the reasons for starting and developing a business is one of the most fundamental in entrepreneurship research, conclusions have not been reached [32]. Discussion is conducted both from the perspective of entrepreneurial intentions and entrepreneurial activities [32]. Generally, the factors impacting the process of new company creation can be distinguished into personal ones, related to the entrepreneurs; factors related to new company's assets; and external ones, related to the economic, social, technological, and cultural environment [37]. Among the personal factors affecting the start-up process, the following are mentioned: need for achievement, internal locus of control, proactiveness, initiative [38], education level [39], attitude towards risk [40], or prior entrepreneurial experience [41], just to mention a few. The internal initial resources of newly-created companies are the next set of factors impacting the start-up process, such as, for example, financial capital [42,43], qualification of employees, or R\&D activities [36]. The role of initial resources is bimodal as they not only affect the start-up process itself but also determine access to other key resources and help overcome some entry barriers [44,45].

The next group of determinants of the start-up process is related to the environment of a newly-established company. Research results show a very diversified set of factors, such as, for example: the economic size of the region [39] and regional characteristics [41], the kind of industrial regime [46], imperfection in the financial markets [47], access to human resources in a region [48], or access to entrepreneurial ecosystems and networks $[49,50]$.

The most recent attitude to the environment of entrepreneurs is included in the concept of the entrepreneurial ecosystem, the digital entrepreneurial ecosystem [49,51], or even the innovation ecosystem [52], which highlights the special importance of the quality of the entrepreneurial ecosystem for the entrepreneurial initiatives [53]. The concept of the entrepreneurial ecosystem is transferred from the natural sciences, where ecosystem means the interactions between two components, a community of living organisms and their non-living components, and is characterized by openness, dynamics, context-specificity, and resilience [54]. The entrepreneurial ecosystem consists of a set of interrelated economic, social, and institutional factors supporting entrepreneurial ventures by providing the necessary conditions for their development and commercialization [55]. The entrepreneurial ecosystem is also perceived as a geographical space of co-located organizations of different kinds, such as start-ups, established companies, experienced entrepreneurs, research universities and organizations, and the networks between them [56]. A spatial concentration of established companies and institutions, by transforming the local environment, fosters 
the market entrance of start-ups [57]. A healthy entrepreneurial ecosystem can support the capacity to marginalize the effects of high start-up rates independently from their quality [33].

There are several kinds of institutions that create the innovation and conditions for knowledge creation, diffusion, and commercialization in entrepreneurial ecosystems. In these contexts, the role of such organizations as universities and other research organizations [56,58], technology centers and research institutions, science and technological parks, university spin-off companies [59], and local governments [57] are the most often analyzed. However, the institutional support of banks and financial institutions in providing finances, as well as law firms to protect intellectual property rights, are also highlighted [60].

The universities are institutions of special importance for regional economic growth, which is highlighted in one of the models of entrepreneurial ecosystem, known as universitybased entrepreneurial ecosystem $[59,61]$. The special role of universities is related to their aims at fostering entrepreneurial thinking and networking [61]. There are several core actors of university entrepreneurial ecosystems, such as technology transfer officers, academic and external entrepreneurs, investors, and business incubators [62]. Among them, university spin-off companies are recognized as main actors of the ecosystem that strengthen the transfer of knowledge through relationships with other businesses [59].

The mentioned elements of entrepreneurial ecosystem can be treated as formal ones as they represent formal institutions, however, norms, rules, entrepreneurial culture etc., known as informal institutions, also shape the activity of entrepreneurs and by that informal entrepreneurial ecosystem can be distinguished [61].The impact of innovation on the startup process is not a new problem, as it has been considered from the individual point of view of innovativeness as a personal feature of nascent entrepreneurs [63,64], as a problem of R\&D investments for a newly-created company [65], development strategy [52], or as a feature of the region of a new company's location [66]. Innovative ideas coming from start-ups are also analyzed [67] as well as the importance of external financial resources to support the process of innovation in newly-created companies [68]. The impact of innovation can also be perceived from the perspective of the innovation ecosystem. Within this concept, knowledge and technology are created, disseminated, and used through the interaction of geographically-close actors and their relations, including organizations, companies, research centers, and policymakers [69], as the geographical proximity of innovation actors supports the exchange of tacit knowledge [70]. Cluster initiatives are often these intermediaries that support innovation in geographical proximity [71].

As high-tech industries are geographically located in some areas, through their interactions with other actors, it can be assumed that their activities affect local business conditions. Co-location in regional clusters, especially in high-tech industries, supports knowledge spillovers through the interpersonal ties of managers and entrepreneurs [72].

The general connotation of the entrepreneurial or innovation ecosystem is that these ecosystems should support the companies operating within them. However, as companies are heterogeneous and their aims are often competitive or even conflicting, the impact of systems are not equal for all actors. Such observation is in line with the concept of industrial regimes, which discusses the diversification of environmental impacts on innovation activities. It distinguishes the existences of two kind of industrial regimes: an entrepreneurial and a routinized regime, related to the fact that innovations can be launched on the market by both start-up companies and established companies [73]. The entrepreneurial regime is characterized by a relatively high share of start-up companies that implement innovations in the market, displacing established companies from the market, and is related to creative destruction. In a routinized regime, innovations are launched by established companies, which limits the market entry of new companies and supports creative accumulation $[46,74,75]$.

Whenever high-tech internationalization is considered from the point of view of environmental factors, the most common research perspective analyzes the impact of the host country's characteristics on the overseas activities of high-tech companies [76], or 
from the perspective of the entrepreneurial ecosystem, with high-tech companies as the key players supported by the ecosystem [54]. However, as the essence of an ecosystem assumes interrelations between living organisms and their habitats, it can be also assumed that the high-tech industry interrelates with other market players and environmental conditions. The novelty of the present paper is to accept this perspective and assess whether and how the internationalization of the high-tech industry affects the country's entrepreneurial entry by shaping local conditions for new entrances. High-tech companies, even though globally active due to their internationalization, operate in some local, regional, and national environments, and through that, they interact with the regional and national entrepreneurial ecosystems.

\section{Methodology and Research Results}

\subsection{Research Questions Development}

The impact of high-tech internationalization on the start-up process can be considered an environmental factor of the entrepreneurial ecosystem from several perspectives. Such assumption is in line with the observation that the relationship between institutions and entrepreneurship is bi-directional; entrepreneurship not only acts in institutional environment but also creates it [77]. First of all, the activity of the high-tech industry shapes the market conditions by affecting the innovativeness of a region [8], investments in $R \& D$, or the demand for a highly-qualified labor force. Second, the internationalization of the high-tech industry also affects the transfer of global trends into the region and makes the environment more sensitive to international markets. All together, these theoretical discussions lead to asking the research question (RQ.1) of whether the internationalization of the high-tech industry creates a competitive and innovative environment in the entrepreneurial ecosystem that impacts the start-up process.

RQ.1. Does the internationalization of the high-tech sector contribute to the start-up process of new company creation from a country macro-level perspective?

There are several approaches to estimating entrepreneurial ecosystems, which leads to theoretically justifying the impact of the high-tech industry and its internationalization on the entrepreneurial ecosystem. Some approaches were developed by such institutions as, for example, the Global Entrepreneurship Monitor (GEM) (https:/ / gemconsortium.org/), (accessed on 30 April 2021) and others by independent researchers [i.e., 33, 54]. GEM assumes the existence of nine conditions of new business creation; some of them are related to national policy (i.e., governmental policies or governmental programs) or regional policy (i.e., physical infrastructure); however, there are also some aspects that might be impacted by the high-tech industry and its internationalization, such as, for example, R\&D transfer or market dynamics. Accepting the idea of the regional entrepreneurship and development index (REDI) sub-indexes, pillars, and variables [33], the internationalization of the high-tech industry can influence several aspects of the ecosystem; for example, the level of innovation from knowledge creation and dissemination, globalization and open society, competition and networking, or human capital. Accepting the existence of entrepreneurial ecosystem pillars such as, for example: financial or funding, regulatory framework or policies, culture, education or human capital, market, etc. [54], high-tech internationalization may affect the market conditions by networking and innovation diffusion; human capital by employing highly qualified employees; and cultural openness by operating in an international environment with cultural diversity. Another model proposed by [78] assumes that the entrepreneurial ecosystem consists of institutional arrangements (including formal institutions, culture, and networks) and resource endowments (including physical infrastructure, demand, intermediaries, talent, knowledge, leadership, and finance), which work together to support productive entrepreneurship as an output. Following this model, the internationalization of the high-tech industry can impact the entrepreneurial ecosystem by shaping networks in the ecosystem, by creation of demand for local employees and suppliers with high-skilled services, and by knowledge transfer, just to mention the most important aspects. 
However, as the concept of entrepreneurial and routinized regimes [46,73-75] indicates, the impact of the innovativeness of established companies on the process of new company creation can be both positive and negative. In some industries with creative accumulation, the innovativeness of existing companies prevents new entrances; in others, with creative destruction, innovations are mainly introduced by start-ups. Combining these two perspectives leads to the formulation of research question (RQ.2.): whether the expected influence of high-tech internationalization on the start-up process depends on the characteristics of the level of international openness of the high-tech industry, and if yes, in which group of countries this influence is stronger (RQ.3).

RQ.2. To what extent is the expected effect of high-tech internationalization on start-up activities moderated by the level of international openness of the high-tech industry?

RQ.3. In which group of countries, with lower or with higher level of high-tech internationalization, is this assumed influence stronger?

To answer these research questions, first, the conceptual model assumed in the paper was created (Figure 1). Both kind of actors, high-tech companies and newly-created companies, operate in the same entrepreneurial ecosystem; however, the length of participation in the high-tech ecosystem is far longer than start-ups, as start-ups are newcomers to the ecosystem. Due to this, high-tech companies, through their innovativeness and openness to global markets, co-shape the conditions of the ecosystem through their interactions with other actors, and in consequence, affect start-up activities.

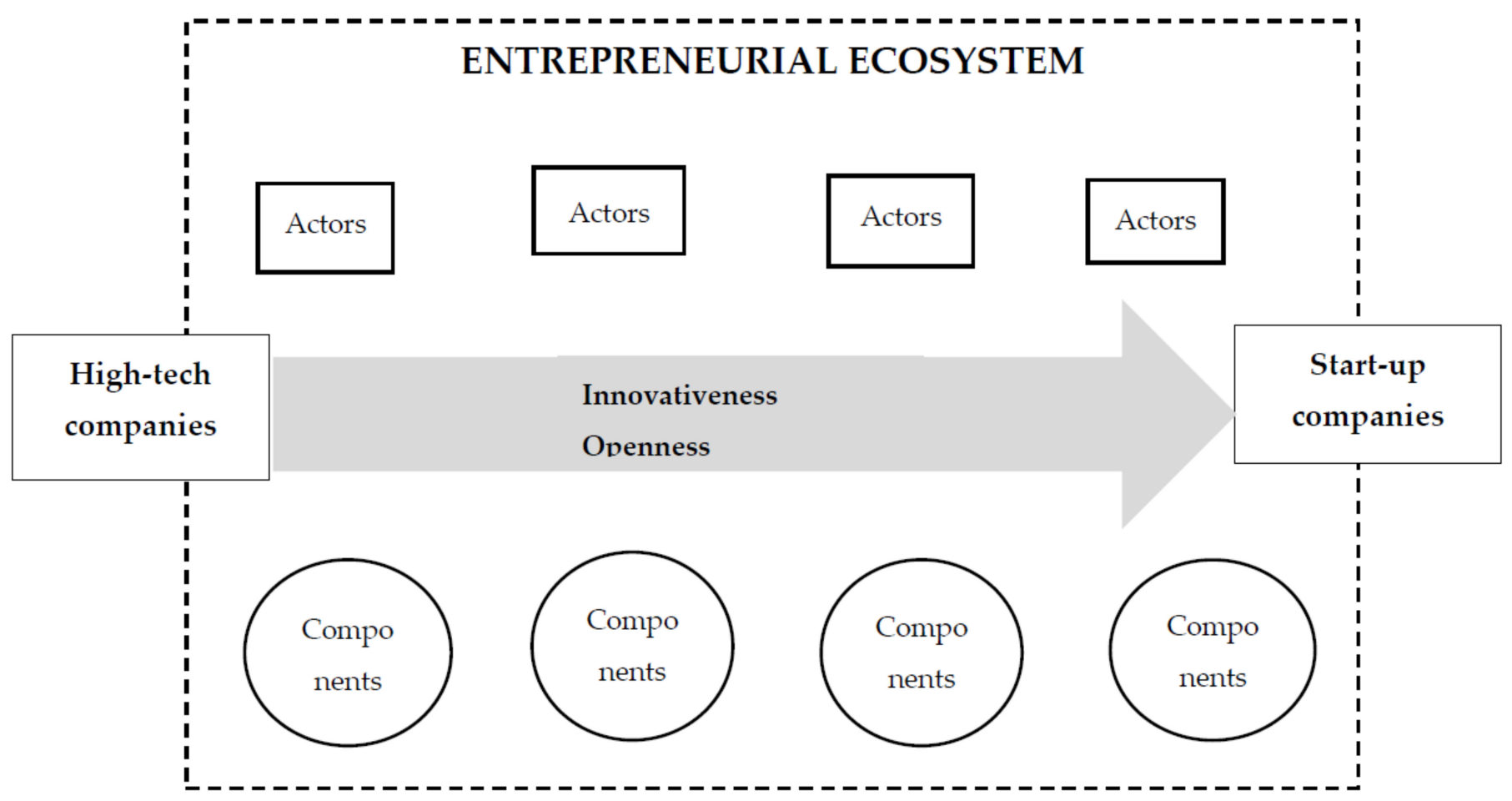

Figure 1. Conceptual model of high-tech internationalization's influence on start-up activities.

\subsection{Research Method and Results}

To answer these research questions, based on the concept presented in Figure 1, the empirical analysis was designed and conducted. First of all, the countries for study were selected, and initially, European Union (EU) countries were considered for the research for two reasons. European Union countries represent relatively similar levels of institutional background, especially in the context of a common political framework of international and innovation policies. Additionally, free international trade within the European Union, based on the free flow of products, services, capital, and people as a basic value of the 
$\mathrm{EU}$, leads to distinguishing the internationalization of the high-tech industry in intra-EU and extra-EU contexts. First, $27 \mathrm{EU}$ countries were considered in the research (without the UK, due to the results of the referendum on Brexit and the preparations for leaving the EU); however, two countries were eventually excluded because of a lack of data: Croatia and Greece. Finally, data from the following $25 \mathrm{EU}$ countries were incorporated into the research: Austria, Belgium, Bulgaria, Cyprus, Czechia, Denmark, Estonia, Finland, France, Germany, Hungary, Ireland, Italy, Latvia, Lithuania, Luxembourg, Malta, The Netherlands, Poland, Portugal, Romania, Slovakia, Slovenia, Spain, and Sweden. The research period was the years 2009-2018 on an annual basis, which led to creating a panel of data for 25 countries, multiplied by 10 years of observations.

The next research step was to select the dependent, independent, and control variables. Start-up rates, being the share of newly-created companies in the total number of enterprises, were selected as the dependent variable. Internationalization is not equal to the internationalization of sales, and there is criticism of this attitude, as high-tech companies are also active internationally in other fields [16]; however, the international trade of this sector is accepted in the paper as a variable affecting the start-up process. Altogether, four independent variables were selected: import of high-tech industry intra-European Union, import of high-tech industry extra-European Union, export of high-tech industry intra-European Union, and export of high-tech industry extra-European Union. The share of employment in the high-tech industry in total employment was treated as a control variable showing the economic importance of the high-tech sector. The list of selected variables is presented in Table 1, together with their mean (M) and standard deviation (SD) values for the years 2009-2018 in the countries of research.

Table 1. List of variables, their abbreviations and descriptive statistics for all analysed countries in years 2009-2018.

\begin{tabular}{|c|c|c|c|c|}
\hline Variable & Abb. & Operationalization & $\mathbf{M}$ & SD \\
\hline Start-up rate & SR & $\begin{array}{l}\text { Start-up rate being a number of enterprise } \\
\text { births in the reference period }(\mathrm{t}) \text { divided by } \\
\text { the number of enterprises active in } \mathrm{t}(\text { in } \%)\end{array}$ & 10.39 & 3.64 \\
\hline $\begin{array}{l}\text { Intra-EU import of } \\
\text { high-tech industry }\end{array}$ & IMPINTRA & $\begin{array}{l}\text { Total high-tech Intra-EU28 (2013-2020) } \\
\text { import as a percentage of total import (in \%) }\end{array}$ & 11.15 & 3.65 \\
\hline $\begin{array}{l}\text { Extra-EU import of } \\
\text { high-tech industry }\end{array}$ & IMPEXTRA & $\begin{array}{l}\text { Total high-tech Extra-EU28 (2013-2020) } \\
\text { import as a percentage of total import (in \%) }\end{array}$ & 17.74 & 13.45 \\
\hline $\begin{array}{l}\text { Intra-EU export of } \\
\text { high-tech industry }\end{array}$ & EXPINTRA & $\begin{array}{c}\text { Total high-tech Intra-EU28 (2013-2020) export } \\
\text { as a percentage of total export (in \%) }\end{array}$ & 10.81 & 6.07 \\
\hline $\begin{array}{l}\text { Extra-EU export of } \\
\text { high-tech industry }\end{array}$ & EXPEXTRA & $\begin{array}{l}\text { Total high-tech Extra-EU28 (2013-2020) } \\
\text { export as a percentage of total export (in \%) }\end{array}$ & 14.76 & 9.68 \\
\hline $\begin{array}{l}\text { Employment in } \\
\text { high-tech industry }\end{array}$ & EMPHT & $\begin{array}{l}\text { Employment in high and medium } \\
\text { high-technology manufacturing as a } \\
\text { percentage of total employment (in \%) }\end{array}$ & 5.03 & 2.74 \\
\hline
\end{tabular}

The next research step was to conduct a cluster analysis in order to divide the EU countries into homogeneous groups with a similar level of high-tech internationalization. The cluster analysis was based on data for 2018 as the end of research period, and all four variables of high-tech internationalization were implemented in the analysis: intra-EU import of high-tech industry, extra-EU import of high-tech industry, intra-EU export of high-tech industry, and extra-EU export of high-tech industry. The number and members of clusters were determined based on Ward's minimum variance technique, with the assumption that all variables that differentiate clusters should be at the significance level of $p<0.05$. Details are presented in Table 2 . 
Table 2. Between and within cluster variance in cluster analysis for year 2018.

\begin{tabular}{ccccccc}
\hline Variables & Between Clusters & df & Within Clusters & df & F-Value & $p$-Value \\
\hline IMPINTRA & 255.846 & 2 & 104.536 & 22 & 26.922 & 0.000 \\
\hline IMPEXTRA & 3420.687 & 2 & 568.704 & 22 & 66.164 & 0.000 \\
\hline EXPINTRA & 448.282 & 2 & 433.420 & 22 & 11.377 & 0.000 \\
\hline EXPEXTRA & 1523.898 & 2 & 775.400 & 22 & 21.618 & 0.000 \\
\hline
\end{tabular}

This method led to identifying three clusters; their descriptive statistics and members are presented in Table 3. However, cluster 1 consists just of one country (Ireland), while the other clusters consist of nine (cluster 2) or 15 (cluster 3) countries. Comparing the descriptive statistics of clusters with mean and standard deviation values for all samples (Table 1), cluster 1 is characterized by an extremely high level of internationalization of the high-tech sector, and cluster 2 by a relatively higher level of high-tech internationalization, while cluster 3 has a relatively lower level. The average intra-EU import is quite similar in cluster 2 and cluster 3 ; however, the biggest differences between these two clusters are related to extra-EU import and extra-EU export.

Table 3. Descriptive statistics of clusters.

\begin{tabular}{|c|c|c|c|c|c|c|}
\hline \multirow[t]{2}{*}{ Variables } & \multicolumn{2}{|c|}{$\begin{array}{c}\text { Cluster } 1 \\
(N=1)\end{array}$} & \multicolumn{2}{|c|}{$\begin{array}{c}\text { Cluster } 2 \\
(\mathrm{~N}=9)\end{array}$} & \multicolumn{2}{|c|}{$\begin{array}{c}\text { Cluster } 3 \\
(\mathbf{N}=\mathbf{1 5})\end{array}$} \\
\hline & $\mathbf{M}$ & SD & $\mathbf{M}$ & SD & $\mathbf{M}$ & SD \\
\hline IMPINTRA & 27.100 & 0.00 & 11.033 & 2.413 & 10.660 & 2.035 \\
\hline IMPEXTRA & 55.000 & 0.00 & 27.500 & 7.274 & 8.880 & 3.223 \\
\hline EXPINTRA & 26.300 & 0.00 & 14.056 & 4.360 & 8.053 & 4.483 \\
\hline EXPEXTRA & 43.300 & 0.00 & 20.656 & 8.609 & 9.613 & 3.611 \\
\hline $\begin{array}{l}\text { Members of } \\
\text { cluster }\end{array}$ & \multicolumn{2}{|c|}{ Ireland } & \multicolumn{2}{|c|}{$\begin{array}{c}\text { Austria, Czechia, France, Germany, } \\
\text { Hungary, Latvia, Luxembourg, } \\
\text { Malta, The Netherlands }\end{array}$} & \multicolumn{2}{|c|}{$\begin{array}{c}\text { Belgium, Bulgaria, Cyprus, } \\
\text { Denmark, Estonia, Finland, Italy, } \\
\text { Lithuania, Poland, Portugal, } \\
\text { Romania, Slovakia, Slovenia, Spain, } \\
\text { Sweden }\end{array}$} \\
\hline
\end{tabular}

To answer the research question, the estimations of panel regression models were implemented, with start-up rates as the dependent variable, selected measures of high-tech internationalization as independent variables, and employment in high-tech industry as the control variable. Since economic theory assumes models with constant elasticity, the $\log -\log$ model is used based on Equation (1).

$\operatorname{lnSR}_{i t}=\beta_{0}+\beta_{1} \operatorname{lnIMPINTRA}_{i t}+\beta_{2} \operatorname{lnIMPEXTRA~}_{i t}+\beta_{3} \operatorname{lnEXPINTRA}_{i t}+\beta_{4} \operatorname{lnEXPEXTRA} A_{i t}+\beta_{5} \operatorname{lnEMPHT} i t+v_{i t}$

where:

$\operatorname{lnSR}_{i t}$ - natural logarithm of start-up rate in $t$ period and in $i$ country,

lnIMPINTRA $A_{i t}$-natural logarithm of intra-EU import of high-tech industry in $t$ period and in $i$ country,

$\operatorname{lnIMPEXTRA}_{i t}$-natural logarithm of EXTRA-EU import of high-tech industry in $t$ period and in $i$ country,

$\operatorname{lnEXPINTRA}{ }_{i t}$-natural logarithm of intra-EU export of high-tech industry in $t$ period and in $i$ country,

$\operatorname{lnEXPEXTRA}{ }_{i t}$-natural logarithm of EXTRA-EU export of high-tech industry in $t$ period and in $i$ country, 
$\operatorname{lnEMPHT}_{i t}$-natural logarithm of employment in high-tech industry in $t$ period and in $i$ country,

$\beta_{0}, \beta_{1}, \beta_{2}, \beta_{3}, \beta_{4}, \beta_{5}$-vectors (constant and parameters or regression coefficients).

To assess both the general relationships in all European Union countries and in clusters of EU countries, the parameters and fit statistics of Equation (1) were estimated separately for the full sample of analyzed countries and for clusters. However, as cluster 1 consisted of just one country, the model for this cluster was not estimated, as the number of observations was too low. To exclude the problem of collinearity among variables, the analyses of variance inflation factors (VIFs) were conducted for both the full sample and two clusters, with start-up rates as the dependent variable, measures of high-tech internationalization as independent variables, and employment in the high-tech industry as the control variable. As results (Table 4) indicate, all values of the VIFs are lower than 10, meaning that collinearity was not detected, and all variables were implemented into the estimations of models.

Table 4. VIFs results.

\begin{tabular}{cccr}
\hline Variables & Model for Full Sample & Model for Cluster 2 & Model for Cluster 3 \\
\hline lnIMPINTRA & 1.838 & 3.073 & 1.830 \\
\hline $\operatorname{lnIMPEXTRA~}$ & 2.949 & 2.174 & 2.472 \\
\hline $\operatorname{lnEXPINTRA~}$ & 3.043 & 2.505 & 2.025 \\
\hline $\operatorname{lnEXPEXTRA~}$ & 3.096 & 2.484 & 1.516 \\
\hline $\operatorname{lnEMPHT}$ & 1.581 & 2.284 & 2.174 \\
\hline
\end{tabular}

Then, to determine the manner of regression modelling among least squares method, panel regression with fixed effects (FE) or panel regression with random effects (RE), the Breusch-Pagan tests and Hausman tests were conducted (Table 5). The P-values of all Breusch-Pagan tests below $(<0.05)$ mean that the classical least squares method of model estimations was rejected in favor of the panel regression method. The nature of the effects in panel models was determined based on the Hausman test, the low values $(<0.05)$ of which indicate the use of a model with fixed effects (cluster 2), while values over $(<0.05)$ indicate the use of a model with random effects (full sample with $p=0.754$ and cluster 3 with $p=0.246)$.

Table 5. Results of the Breusch-Pagan and Hausman tests of models with $\ln S R$ as dependent variable.

\begin{tabular}{cccccc}
\hline \multicolumn{2}{c}{ Tests } & & Model for Full Sample & Model for Cluster 2 & Model for Cluster 3 \\
\hline \multirow{2}{*}{ Breusch-Pagan test } & LM & 577.498 & 15.078 & 346.839 \\
\cline { 2 - 5 } & & $\mathrm{P}$ & 0 & 0 & 0 \\
\hline \multirow{2}{*}{ Hausman test } & $\mathrm{H}$ & 2.650 & 31.699 & 6.6713 \\
\cline { 2 - 5 } & & $\mathrm{P}$ & 0.754 & 0 & 0.246 \\
\hline
\end{tabular}

Having all variables accepted and the estimation method determined, the last research step was to estimate the parameter values of panel models, as well as their fit statistics (Table 6). Models for the full sample of selected $25 \mathrm{EU}$ countries and for two clusters (cluster 2 with relatively higher and cluster 3 with relatively lower level of high-tech internationalization) were estimated. As already explained, cluster 1 was excluded from this research step due to just one country being assigned to this cluster. 
Table 6. Results of panel model estimations for start-up rates as dependent variable (lnSR).

\begin{tabular}{|c|c|c|c|}
\hline \multirow{2}{*}{ Variables } & Model for Full Sample & Model for Cluster 2 & Model for Cluster 3 \\
\hline & Panel with Random Effects & Panel with Fixed Effects & Panel with Random Effects \\
\hline \multicolumn{4}{|c|}{ Values and statistical significance of models' parameters } \\
\hline Const. & $\begin{array}{c}3.174 * * * \\
(0.208)\end{array}$ & $\begin{array}{c}4.116 * * * \\
(0.448)\end{array}$ & $\begin{array}{c}2.768^{* * *} \\
(0.284)\end{array}$ \\
\hline lnIMPINTRA & $\begin{array}{c}-0.332 * * * \\
(0.093)\end{array}$ & $\begin{array}{c}-0.339 * \\
(0.179)\end{array}$ & $\begin{array}{c}-0.302 * * \\
(0.130)\end{array}$ \\
\hline InIMPEXTRA & $\begin{array}{l}-0.064 \\
(0.062)\end{array}$ & $\begin{array}{c}-0.358^{* * *} \\
(0.118)\end{array}$ & $\begin{array}{c}0.028 \\
(0.079) \\
\end{array}$ \\
\hline $\operatorname{lnEXPINTRA}$ & $\begin{array}{c}0.169 * * * \\
(0.061)\end{array}$ & $\begin{array}{c}0.310 * * * \\
(0.107)\end{array}$ & $\begin{array}{c}0.112 \\
(0.072) \\
\end{array}$ \\
\hline $\operatorname{lnEXPEXTRA~}$ & $\begin{array}{c}-0.177^{* * *} \\
(0.046)\end{array}$ & $\begin{array}{c}-0.278^{* * *} \\
(0.090)\end{array}$ & $\begin{array}{c}-0.217^{* * *} \\
(0.051)\end{array}$ \\
\hline $\operatorname{lnEMPHT}$ & $\begin{array}{c}0.090 \\
(0.072)\end{array}$ & $\begin{array}{l}0.100 * \\
(0.057)\end{array}$ & $\begin{array}{c}0.300 * * * \\
(0.105)\end{array}$ \\
\hline \multicolumn{4}{|c|}{ Fit statistics of models } \\
\hline Fit statistics & $\begin{array}{c}\text { 'Between' variance }=0.090 \\
\text { 'Within' variance }=0.023 \\
\mathrm{~N}=246\end{array}$ & $\begin{array}{c}\text { LSDV R }^{2}=0.647 \\
\text { Within } \mathrm{R}^{2}=0.396 \\
\mathrm{~N}=88\end{array}$ & $\begin{array}{l}\text { 'Between' variance }=0.110 \\
\text { 'Within' variance }=0.020 \\
\qquad N=149\end{array}$ \\
\hline
\end{tabular}

Note: standard errors in parentheses, statistically significant parameters are in bold. ${ }^{* * *} p<0.01 ;{ }^{* *} p<0.05,{ }^{*} p<0.1$.

As the models were estimated based on a different number of observations ( 25 countries and $\mathrm{N}=246$ in full sample, 9 countries and $\mathrm{N}=88$ in cluster 2, and 15 countries and $\mathrm{N}=149$ in cluster 3), and both random (full sample and cluster 3) and fixed (cluster 2) effects in the panel method, all discussion and comparisons were based on the statistical significance and values of the model parameters of independent variables (respectively, $\beta_{1}$, $\beta_{2}, \beta_{3}$ and $\beta_{4}$ according to general Equation (1), not on fit statistics. Generally, variables related to international trade in the high-tech industry were statistically significant in explaining start-up rates in European Union countries, both intra- and extra-EU international trade, and both import and export.

In the case of the model for the full sample of EU countries, such measures as intraEU import, intra-EU export, and extra-EU export of high-tech industry were statistically significant in explaining the start-up rates. Intra-EU import and extra-EU export of the high-tech industry affected start-up rates negatively, while intra-EU export affected it positively. Comparing the absolute values of the parameters, the effect of intra-EU import appeared to be the highest among the analyzed independent variables. When the model for cluster 2 of the relatively higher openness of high-tech industry was considered, the parameters of all four analyzed independent variables were statistically significant in explaining the start-up rates. Most of them (intra- and extra-EU import and extra-EU export) impacted negatively; only one, extra-EU import of the high-tech industry, affected positively. The absolute values of the parameters were of comparable heights, with slightly higher values of import variables. The model for cluster 3 , with a relatively lower level of high-tech openness, indicated only two, out of the considered four, independent variables as statistically significant. Intra-EU import and extra-EU export of high-tech industry were statistically significant in explaining the start-up rates, both of them in a negative fashion.

General observation, related to research question RQ.1, can indicate that the international trade of the high-tech industry is a factor that contributes to the start-up process; however, it does so in a rather limiting manner. The assumption made in the paper that, through its innovativeness and openness, the high-tech sector affects the interactions in the entrepreneurial ecosystem gets indirect support. However, the influence of high-tech 
openness on the start-up process seems to be rather limiting, as most of variable parameters are negative. These results are also in line with the recognition that the innovativeness of established companies can be a factor, which may lead to difficulties in imitating them, and in consequence, it might lead to a smaller level of market entrance of new companies [79].

As free movement of products and services within the European Union is one of the fundamental values, the impact of intra-EU international trade should be discussed separately. Intra-EU high-tech import looks to limit the start-up rates in all models; it seems that the possibility to import high-tech products without any customs restrictions makes the national entrepreneurial ecosystem more competitive and, at the same time, creates more space for new market entrance in exporting countries, as intra-EU high-tech export supports start-up activities, especially in countries with a relatively higher level of high-tech openness.

High-tech international trade outside the EU also limits the national start-up rates, especially extra-EU export, which is significant in all models. As extra-EU export is related not only to customs restrictions but also to global competition, the higher level of extra-EU high-tech export might be interpreted as a measure of highly competitive and developed technological and innovative competences, as well as international sales competences in global market. It requires reaching a high level of business and technological maturity of the high-tech industry, and it might constitute a barrier for new companies to enter the market by supporting creative accumulation.

Answering research question RQ.2, the level of international trade of high-tech in a country moderates its effect on start-up rates. The cluster analysis led to distinguishing a cluster of countries with relatively different levels of high-tech openness, and there were some differences in the analyzed relationship. The direction of interactions between measures of high-tech international trade and start-up rates were the same in both clusters of countries; however, in the case of clusters of countries with a relatively higher level of high-tech international trade, all variables that measure the openness of high-tech industry were statistically significant in explaining the start-up rates, while in the case of clusters with a relatively lower level, just half of the variables were statistically significant. This comparison, answering research question RQ.3, led to the assumption that the impact of high-tech internationalization on start-up rates was stronger in those countries with a higher level of high-tech openness.

\section{Discussion and Conclusions}

The high-tech sector: although globally active through the process of internationalization, is also located in some space and is part of a local and national entrepreneurial ecosystem, interacting with its local actors. The internationalization of the high-tech industry, therefore, includes two aspects of great importance for the start-up process within entrepreneurial ecosystems: global openness and innovativeness. However, as the concepts of entrepreneurial and routinized regimes, followed by creative destruction and creative accumulation suggest [46,73-75], both of these aspects might support or limit the market entrance of new companies. These theoretical considerations, especially due to their unclear direction of potential influence, lead to formulating the following research questions: Does the internationalization of the high-tech sector contribute to the start-up (RQ.1)? To what extent is the expected effect of high-tech internationalization on start-up activities moderated by the level of international openness of the high-tech industry (RQ.2)? In which group of countries, with lower or with higher level of high-tech internationalization, is assumed influence stronger (RQ.3)?

Answers to these research questions were sought on the basis of panel data for European Union countries for the years 2009-2018, with the use of cluster analysis and panel regression modelling. The cluster analysis led to distinguishing clusters of European Union countries with a different level of internationalization of the high-tech industry, which indicated internal differentiation among EU member states. Results for estimation of the panel regression models, both for the sample of all EU countries and separately 
for clusters of countries, led to answering RQ.1: the international trade of the high-tech industry is a factor which contributes to the start-up process; however, this influence is of a rather limiting nature. High-tech openness affects the start-up process mostly negatively, which might be related to the existence of the destructive accumulation phenomenon and the difficulties for newly-created companies to imitate the innovativeness and openness of established companies.

Comparing the results of the models for the sample of all EU countries, and for both clusters, it can be observed that the level of high-tech international trade in each country moderates its effect on start-up rates (RQ.2). On the one hand, the direction of interactions between measures of high-tech international trade and start-up rates are the same in both clusters of countries. On the other hand, however, the main difference between clusters is related to the scale of impact. In the case of clusters of countries with a relatively higher level of high-tech international trade, all variables that measure the openness of high-tech industry were statistically significant in explaining the start-up rates, while in the case of the cluster with a relatively lower level, just half of the variables were statistically significant.

This observation also led to answering research question RQ.3. A stronger impact of the high-tech internationalization on the rate of creation of new enterprises is observed in the cluster of countries with a relatively higher level of international openness.

These research results might have some implications for policies supporting entrepreneurship, innovativeness, and internationalization of industries in order to make the high-tech internationalization and start-up processes balanced. On the other hand, the research has also its limitations, mostly related to the availability and nature of the panel data. As research was limited to European Union countries, first of all, results show relationships existing only in an EU institutional context and at a macro level, meaning that in the context of other parts of the world, as well as in the context of particular countries, entrepreneurial ecosystems or companies are missed.

Funding: The APC was funded by Poznan University of Economics and Business, Poland.

Institutional Review Board Statement: Not applicable.

Informed Consent Statement: Not applicable.

Data Availability Statement: Data used in the paper based on Eurostat (publicly archived dataset of the European Statistical Office) and their online source.

Conflicts of Interest: The author declare no conflict of interest.

\section{References}

1. Chung, J.Y.; Yoon, W. Technological capabilities and internationalization of high-tech ventures: The moderating role of strategic orientations. Manag. Decis. Econ. 2020, 41, 1462-1472. [CrossRef]

2. Laužikas, M.; Miliūtè, A.; Khalili, M. Internationalization impacts on team innovation in Lithuanian high-tech firms. Insights Reg. Dev. 2021, 3, 41-64. [CrossRef]

3. Crick, D.; Crick, J.M. The internationalization strategies of rapidly internationalizing high-tech UK SMEs. Planned and unplanned activities. Eur. Bus. Rev. 2014, 26, 421-448. [CrossRef]

4. Daszkiewicz, N. Foreign Entry Modes of High-Tech Firms in Poland. Studia UBB Negotia 2017, 62, 23-34. [CrossRef]

5. Lin, R.; Che, R.; Ting, C. Turning knowledge management into innovation in the high-tech industry. Ind. Manag. Data Syst. 2012, 112, 42-63. [CrossRef]

6. Liu, Y.; Kim, J.; Yoo, J. Intangible Resources and Internationalization for the Innovation Performance of Chinese High-Tech Firms. J. Open Innov. Technol. Mark. Complex. 2019, 5, 52. [CrossRef]

7. Mejri, I.; Ramadan, M. Network relationships and internationalization in Tunisian high-tech SMEs. Glob. Bus. Organ. Excel. 2017, 37, 39-47. [CrossRef]

8. Ze-Lei, X.; Xin-Ya, D.; Fei, F. Convergence in China's high-tech industry development performance: A spatial panel model. Appl. Econ. 2017, 49, 5296-5308. [CrossRef]

9. Koellinger, P. Why are some entrepreneurs more innovative than others? Small Bus. Econ. 2008, 31, 21-37. [CrossRef]

10. Lejpras, A. How innovative are spin-offs at later stages of development? Comparing innovativeness of established research spin-offs and otherwise created firms. Small Bus. Econ. 2014, 43, 327-351. [CrossRef]

11. Bhattacharya, M.; Bloch, H. Determinants of Innovation. Small Bus. Econ. 2004, 22, 155-162. [CrossRef] 
12. Simonen, J.; McCann, P. Innovation, R\&D cooperation and labor recruitment: Evidence from Finland. Small Bus. Econ. 2008, 31, 181-194. [CrossRef]

13. Esteve-Pérez, S.; Mañez-Castillejo, J.A. The Resource-Based Theory of the Firm and Firm Survival. Small Bus. Econ. 2008, 30, 231-249. [CrossRef]

14. Bužavaitè, M.; Ščeulovs, D.; Korsakienè, R. Theoretical approach to the internationalization of SMEs: Future research prospects based on bibliometric analysis. Entrep. Sustain. 2019, 6, 1497-1511. [CrossRef]

15. Daszkiewicz, N. Internationalisation of Born Globals from the Theoretical Perspective. Probl. Zarzadzania Manag. Issues 2015, 13, 70-81. [CrossRef]

16. Hewerdine, L.J.; Rumyantseva, M.; Welch, C. Resource scavenging. Another dimension of the internationalisation pattern of high-tech SMEs. Int. Mark. Rev. 2014, 31, 237-258. [CrossRef]

17. Moen, O.; Servais, P. Born Global or Graduate Global? Examining the Export Behaviour of Small and Medium-Sized Enterprises. J. Int. Mark. 2002, 10, 49-72. [CrossRef]

18. Ferencikova, S.; Hluskova, T. Internationalization of Central and Eastern European companies-Theory and its implications in the Slovak IT sector. J. East Eur. Manag. Stud. 2015, 20, 415-434. [CrossRef]

19. Bjorgum, O.; Moen, O. New ventures in an emerging industry: Access to and use of international resources. Int. J. Entrep. Small Bus. 2013, 20, 233. [CrossRef]

20. Daszkiewicz, N.; Wach, K. Motives for Going International and Entry Modes of Family Firms in Poland. J. Intercult. Manag. 2014, 6, 5-18. [CrossRef]

21. Hennart, J. The Accidental Internationalists: A Theory of Born Globals. Entrep. Theory Pr. 2014, 38, 117-135. [CrossRef]

22. Mainela, T.; Puhakka, V. Role of networks in emergence of international new ventures. Int. J. Entrep. Ventur. 2011, 3, 5-25. [CrossRef]

23. Bigos, K.; Michalik, A. The influence of innovation on international new ventures' exporting in Central and Eastern Europe and Central Asia countries. Entrep. Bus. Econ. Rev. 2020, 8, 47-63. [CrossRef]

24. Neubert, M.; Van Der Krogt, A. Lean internationalisation of high-tech firms. Int. J. Teach. Case Stud. 2017, 8, 133. [CrossRef]

25. Li, L.; Qian, G.; Qian, Z. Early internationalization and performance of small high-tech "born-globals". Int. Mark. Rev. 2012, 29, 536-561. [CrossRef]

26. Ocampo Figueroa, L.E.; Alarcon Osuna, M.A.; Fong Reynoso, C. Determinants of the Internationalization of the Firm: The Accelerated Model vs the Sequential Model. Int. J. Bus. Financ. Res. 2014, 8, 81-93.

27. Hilmersson, M.; Johanson, M.; Lundberg, H.; Papaioannou, S. Time, Temporality, and Internationalization: The Relationship Among Point in Time of, Time to, and Speed of International Expansion. J. Int. Mark. 2017, 25, 22-45. [CrossRef]

28. Taylor, M.; Jack, R. Born Global Firm Internationalisation: The Influence of Industry Factors. Contemp. Manag. Res. 2016, 12, 289-308. [CrossRef]

29. Wach, K. Innovative Behaviour of High-Tech Internationalized Firms: Survey Results from Poland. Entrep. Bus. Econ. Rev. 2016, 4, 153-165. [CrossRef]

30. Neubert, M.; Van Der Krogt, A.S. Decision-makers impact on the internationalization of high-technology firms in emerging markets. J. Glob. Entrep. Res. 2019, 9, 1-17. [CrossRef]

31. Santarelli, E.; Vivarelli, M. Entrepreneurship and the process of firms' entry, survival and growth. Ind. Corp. Chang. 2007, 16, 455-488. [CrossRef]

32. Zapkau, F.B.; Schwens, C.; Kabst, R. The Role of Prior Entrepreneurial Exposure in the Entrepreneurial Process: A Review and Future Research Implications. J. Small Bus. Manag. 2016, 55, 56-86. [CrossRef]

33. Szerb, L.; Lafuente, E.; Horváth, K.; Páger, B. The relevance of quantity and quality entrepreneurship for regional performance: The moderating role of the entrepreneurial ecosystem. Reg. Stud. 2018, 53, 1308-1320. [CrossRef]

34. Grilo, I.; Thurik, R. Determinants of entrepreneurial engagement levels in Europe and the US. Ind. Corp. Chang. 2008, 17, 1113-1145. [CrossRef]

35. Su, Y.; Wu, N.; Zhou, X. An entrepreneurial process model from an institutional perspective. A multiple case study based on the grounded theory. Nankai Bus. Rev. Int. 2019, 10, 277-305. [CrossRef]

36. Yang, C.; Bossink, B.; Peverelli, P. High-tech start-up firm survival originating from a combined use of internal resources. Small Bus. Econ. 2017, 49, 799-824. [CrossRef]

37. Dileo, I.; Pereiro, T.G. Assessing the impact of individual and context factors on the entrepreneurial process. A cross-country multilevel approach. Int. Entrep. Manag. J. 2019, 15, 1393-1441. [CrossRef]

38. Korunka, C.; Frank, H.; Lueger, M.; Mugler, J. The Entrepreneurial Personality in the Context of Resources, Environment, and the Startup Process-A Configurational Approach. Entrep. Theory Pr. 2003, 28, 23-42. [CrossRef]

39. Naude, W.; Gries, T.; Wood, E.; Meintjies, A. Regional determinants of entrepreneurial start-up in a developing country. Entrep. Reg. Dev. 2008, 20, 111-124. [CrossRef]

40. Caliendo, M.; Fossen, F.M.; Kritikos, A.S. Risk attitudes of nascent entrepreneurs- new evidence from an experimentally validated survey. Small Bus. Econ. 2009, 32, 153-167. [CrossRef]

41. Capelleras, J.-L.; Greene, F.J. The determinants and growth implications of venture creation speed. Entrep. Reg. Dev. 2008, 20, 317-343. [CrossRef] 
42. Seghers, A.; Manigart, S.; Vanacker, T. The Impact of Human and Social Capital on Entrepreneurs' Knowledge of Finance Alternatives. J. Small Bus. Manag. 2011, 50, 63-86. [CrossRef]

43. Reynolds, P.D. Informal and Early Formal Financial Support in the Business Creation Process: Exploration with PSED II Data Set. J. Small Bus. Manag. 2010, 49, 27-54. [CrossRef]

44. Hormiga, E.; Batista-Canino, R.M.; Sánchez-Medina, A. The Impact of Relational Capital on the Success of New Business Start-ups. J. Small Bus. Manag. 2011, 49, 617-638. [CrossRef]

45. Aghion, P.; Fally, T.; Scarpetta, S. Credit constraints as a barrier to the entry and post-entry growth of firms. Econ. Policy 2007, 22, 732-779. [CrossRef]

46. Audretsch, D.B.; Fritsch, M. Growth Regimes over Time and Space. Reg. Stud. 2002, 36, 113-124. [CrossRef]

47. Paulson, A.L.; Townsend, R.M.; Karaivanov, A. Distinguishing Limited Liability from Moral Hazard in a Model of Entrepreneurship. J. Politi. Econ. 2006, 114, 100-144. [CrossRef]

48. Armington, C.; Acs, Z.J. The Determinants of Regional Variation in New Firm Formation. Reg. Stud. 2002, 36, 33-45. [CrossRef]

49. Spigel, B.; Harrison, R. Toward a process theory of entrepreneurial Ecosystems. Strat. Entrep. J. 2018, 12, 151-168. [CrossRef]

50. Song, Y.; Dana, L.P.; Berger, R. The entrepreneurial process and online social networks: Forecasting survival rate. Small Bus. Econ. 2021, 56, 1171-1190. [CrossRef]

51. Song, A.K. The Digital Entrepreneurial Ecosystem-a critique and reconfiguration. Small Bus. Econ. 2019, 53, 569-590. [CrossRef]

52. Feng, N.; Fu, C.; Wei, F.; Peng, Z.; Zhang, Q.; Zhang, K.H. The key role of dynamic capabilities in the evolutionary process for a startup to develop into an innovation ecosystem leader: An indepth case study. J. Eng. Technol. Manag. 2019, 54, 81-96. [CrossRef]

53. Pita, M.; Costa, J.; Moreira, A. Entrepreneurial Ecosystems and Entrepreneurial Initiative: Building a Multi-Country Taxonomy. Sustainability 2021, 13, 4065. [CrossRef]

54. Radinger-Peer, V.; Sedlacek, S.; Goldstein, H. The path-dependent evolution of the entrepreneurial ecosystem (EE)—Dynamics and region-specific assets of the case of Vienna (Austria). Eur. Plan. Stud. 2018, 26, 1499-1518. [CrossRef]

55. Elnadi, M.; Gheith, M.H. Entrepreneurial ecosystem, entrepreneurial self-efficacy, and entrepreneurial intention in higher education: Evidence from Saudi Arabia. Int. J. Manag. Educ. 2021, 19, 100458. [CrossRef]

56. Auschra, C.; Braun, T.; Schmidt, T.; Sydow, J. Patterns of project-based organizing in new venture creation. Projectification of an entrepreneurial ecosystem. Int. J. Manag. Proj. Bus. 2019, 12, 48-70. [CrossRef]

57. Li, Z.; Liu, J.; Wang, F.; Xia, S.; Zhu, X. Projectification and Partnering: An Amalgamated Approach for New Venture Creation in an Entrepreneurial Ecosystem. Emerg. Mark. Finance Trade 2020, 56, 3134-3152. [CrossRef]

58. Ierapetritis, D.G. Discussing the Role of Universities in Fostering Regional Entrepreneurial Ecosystems. Economies 2019, 7, 119. [CrossRef]

59. Fuster, E.; Padilla-Meléndez, A.; Lockett, N.; Del-Águila-Obra, A.R. The emerging role of university spin-off companies in developing regional entrepreneurial university ecosystems: The case of Andalusia. Technol. Forecast. Soc. Chang. 2019, 141, 219-231. [CrossRef]

60. Adams, S.B. From orchards to chips: Silicon Valley's evolving entrepreneurial ecosystem. Entrep. Reg. Dev. 2021, 33, 15-35. [CrossRef]

61. Igwe, P.A.; Odunukan, K.; Rahman, M.; Rugara, D.G.; Ochinanwata, C. How entrepreneurship ecosystem influences the development of frugal innovation and informal entrepreneurship. Thunderbird Int. Bus. Rev. 2020, 62, 475-488. [CrossRef]

62. Prokop, D. University entrepreneurial ecosystems and spinoff companies: Configurations, developments and outcomes. Technovation 2021, 107, 102286. [CrossRef]

63. Arvanitis, S.; Stucki, T. What determines the innovation capability of firm founders? Ind. Corp. Chang. 2012, 21, 1049-1084. [CrossRef]

64. Honjo, Y.; Kato, M.; Okamuro, H. R\&D investment of start-up firms: Does founders' human capital matter? Small Bus. Econ. 2013, 42, 207-220. [CrossRef]

65. Wang, J. R\&D activities in start-up firms: What can we learn from founding resources? Technol. Anal. Strat. Manag. 2014, 26, 517-529. [CrossRef]

66. Fritsch, M.; Schroeter, A. Why does the effect of new business formation differ across regions? Small Bus. Econ. 2011, 36, 383-400. [CrossRef]

67. Homfeldt, F.; Rese, A.; Simon, F. Suppliers versus start-ups: Where do better innovation ideas come from? Res. Policy 2019, 48, 1738-1757. [CrossRef]

68. Korpysa, J. Process Ambidexterity in Startups Innovation. Manag. Syst. Prod. Eng. 2021, 29, 27-32. [CrossRef]

69. Gerli, F.; Chiodo, V.; Bengo, I. Technology Transfer for Social Entrepreneurship: Designing Problem-Oriented Innovation Ecosystems. Sustainability 2020, 13, 20. [CrossRef]

70. Knickel, M.; Neuberger, S.; Klerkx, L.; Knickel, K.; Brunori, G.; Saatkamp, H. Strengthening the Role of Academic Institutions and Innovation Brokers in Agri-Food Innovation: Towards Hybridisation in Cross-Border Cooperation. Sustainability 2021, 13, 4899. [CrossRef]

71. McPhillips, M. Innovation by proxy—Clusters as ecosystems facilitating open innovation. J. Entrep. Manag. Innov. 2020, 16, 101-128. [CrossRef]

72. Schierjott, I.; Brennecke, J.; Rank, O.N. Entrepreneurial Attitudes as Drivers of Managers' Boundary-Spanning Knowledge Ties in the Context of High-Tech Clusters. J. Small Bus. Manag. 2018, 56, 108-131. [CrossRef] 
73. Auerswald, P.E. Entrepreneurship in the Theory of the Firms. Small Bus. Econ. 2007, 30, 111-126. [CrossRef]

74. Lin, P.-C.; Huang, D.-S. Technological Regimes and Firm Survival: Evidence Across Sectors and Over Time. Small Bus. Econ. 2007, 30, 175-186. [CrossRef]

75. Peneder, M.R. Firm entry and turnover: The nexus with profitability and growth. Small Bus. Econ. 2007, 30, 327-344. [CrossRef]

76. Cannone, G.; Ughetto, E. Internationalization flows of high-tech start-ups: A gravity model. Eur. Bus. Rev. 2015, 27, 60-79. [CrossRef]

77. Khalilov, L.; Yi, C.-D. Institutions and entrepreneurship: Empirical evidence for OECD countries. Entrep. Bus. Econ. Rev. 2021, 9, 119-134. [CrossRef]

78. Stam, E.; van de Ven, A. Entrepreneurial ecosystem elements. Small Bus. Econ. 2021, 56, 809-832. [CrossRef]

79. Luttmer, E.G.J. Selection, Growth, and the Size Distribution of Firms. Q. J. Econ. 2007, 122, 1103-1144. [CrossRef] 